\title{
Correction to: The bulk modulus of carbon fibers
}

\section{J. Summerscales ${ }^{1, *}$}

${ }^{1}$ Advanced Composites Manufacturing Centre, Department of Mechanical and Marine Engineering, University of Plymouth, Plymouth PL4 8AA, Devon, UK

\section{Published online:}

10 February 2021

(C) Springer Science+Business Media, LLC, part of Springer

Nature 2021

\section{Correction to:}

Journal of Materials Science Letters 19 (2000) 15-16 https://doi.org/10.1023/A:1006731210592

In the original article there is an error in Eq. (3). The corrected equation follows:

$$
K=\frac{\sqrt[3]{E_{1} E_{2} E_{3}}}{3\left(1-2 \cdot \sqrt[3]{v_{12} v_{31} v_{23}}\right)}
$$

Publisher's Note Springer Nature remains neutral with regard to jurisdictional claims in published maps and institutional affiliations.

The original article can be found online at https: / doi.org/10.1023/A:1006731210592.

Address correspondence to E-mail: jsummerscales@plymouth.ac.uk 